\title{
STUDY ON HYDRODYNAMIC PARAMETERS OF THE OXIDATIVE DESULFURIZATION OF HIGH SULFUR STRAIGHT-RUN OIL FRACTIONS
}

\author{
Serhiy Pyshyev ${ }^{1,}{ }^{\otimes}$, Michael Bratychak ${ }^{1}$
}

https://doi.org/10.23939/chcht14.03.403

\begin{abstract}
The article deals with the determination of hydrodynamic parameters necessary to conduct the desulfurization process of straight-run kerosene (SRKF) and straight-run diesel fractions (SRDF) via oxidation of sulfuric organic compounds, followed by the removal of oxidation products. The established parameters which are characterized by the linear rate of the oxidant (air) movement and the dummy contact time between the oxidant and the feedstock allow the process to be carried out without stirring. The proposed technology can be used for the purification of petroleum fuels produced by a small scale, when hydrotreating is economically unprofitable or technologically impossible. This process can also be used for the aftertreatment of hydrogenates and partial desulfurization of straight-run fractions to produce fuel components with improved lubricating properties.
\end{abstract}

Keywords: sulfur, jet fuel, diesel fuel, oxidative desulfurization, hydrodynamic parameters, lubricity.

\section{Introduction}

Over the last years, the emissions of SOx from combustion fuels have become a serious environmental problem. Strict environmental policies were implemented worldwide limiting the sulfur level in fuels to $10 \mathrm{ppm}$ [1]. Diesel fuel (DF) became a major transportation fuel and also became a big source of pollution. To prevent air pollution caused by exhaust gases the governments of many countries around the world have mandated the sulfur removal from transportation fuels since the past decade. For example, according to the USA specifications the mandatory sulfur content in diesel fuel had to be restricted up to $15 \mathrm{ppm}$ (since July, 2006) [2, 3]. From 2009 the sulfur maximal content in these fuels has to be 10 ppm [3]. The Parliament of the European Union (EU) passed (January $30^{\text {th }}, 2003$ ) a resolution on diesel and gasoline quality (P5_TA-PROV(2003)0029). According

\footnotetext{
${ }^{1}$ Lviv Polytechnic National University,

12, Bandery St., 79013 Lviv, Ukraine

gajva@polynent.lviv.ua

(C) Pyshyev S., Bratychak M., 2020
}

to this regulation, sulfur content in "sulfur-free" fuels has to be no more than $10 \mathrm{ppm}$. In general, all developed countries and many of developing countries had an average value of the sulfur content in transportation fuels about 10 ppm from 2003-2010 [2-4].

In Ukraine, the requirements are not so strict, but the permissible content of sulfur compounds has been significantly reduced in recent years. According to standards of Ukraine it is allowed to produce DF with the sulfur content of $10 \mathrm{ppm}$ and 500-2000 ppm (DSTU 8705:2017); 10, 50 and 350 ppm (DSTU 7688:2015); 10 and $50 \mathrm{ppm}$ (DSTU 4840:2007).

The requirements for the environmental properties of jet fuels (JF) are less strict both in the world and in Ukraine. Therefore, the contribution of aviation to environmental pollution is becoming increasingly noticeable because the sulfur content of JF is $0.1-$ $0.4 \mathrm{wt} \%(1000-4000 \mathrm{ppm})$; for special kinds of JF the sulfur content up to $1.0 \mathrm{wt} \%(10,000 \mathrm{ppm})$ is allowed. This is related to the problems of flight safety, power consumption of jet fuel and its stability during transportation and storage. This approach is also caused by the fact that the major emissions of JF combustion products occur at high altitudes [5-9].

Hydrotreating (HDS), which to date is the main technology for the fuels purification from sulfur compounds, has several disadvantages:

- along with sulfur compounds all other heteroatomic substances are removed and some part of the aromatics is hydrated, which automatically reduces the amount of substances capable of adsorbing on metal surfaces and worsens the lubricating properties of fuels;

- thiophene compounds and other condensed sulfur compounds that may be present in the feedstock are not hydrotreated due to the spatial difficulties occurred during their contact with the catalysts.

In addition, for economic reasons, hydrotreating cannot be organized for small scale production of DF or JF (for example, at plastics and rubber recycling facilities).

Alternative technologies of the straight-run fractions desulfurization have been investigated extensively in the past few decades, including extraction, selective adsorption, biodesulfurization, and oxidative desulfuri- 
zation (ODS). Among these new processes, ODS is considered to be one of the promising new methods and is currently receiving growing attention. The greatest advantage of ODS compared with the conventional HDS process is that it can be carried out in the liquid phase, under very mild conditions, and does not need expensive hydrogen $[1,10]$.

Existing industrial oxidation purification processes are aimed only at the extraction of sour sulfur or at the increase of JF thermo-oxidative stability after hydrotreating. Most ODS processes, which have been developed and improved over the last 20 years, are designed to reduce sulfur content to 10-15 ppm and even less in hydrotreated fuels. These processes, as well as HDS, are relatively complex and require the use of expensive catalysts and oxidizers [11-15].

We are studying the oxidation desulfurization of straight-run kerosene diesel fractions with the high sulfur content, as well as hydrogenates due to their air treatment without the use of expensive catalysts and strong oxidizers. Previously we determined the process main conditions (pressure, fractional composition of feedstocks, the method of sulfur oxidation products separation) and proved that oxidation is desirable to be carried out in the liquid phase in the presence of water [16-18]. We established the effect of temperature and water:feedstock ratio [19] and showed the possibility of obtaining commercial jet fuels [20] and components of diesel fuels with good lubricating properties [21].

It is well known that mixing the reaction medium can affect the delivery rate of the gaseous reagent, its dispersion, etc. On the other hand, the mechanical stirring dramatically increases the energy costs of the process and complicates the equipment design. Therefore, the next stage of experiments and the aim of this work is the choice of optimal hydrodynamic parameters of the process.

\section{Experimental}

\subsection{Experimental Methods and Analyses}

The oxidation was carried out at an enlarged laboratory plant [22]. It consists of a reactor block; air compression and purification systems; gaseous reaction products cooling and recovery system; temperature, pressure, and consumption control and measuring instruments. The main apparatus is a bubble reactor by the volume of 0.71 . The reactor provides the pressure up to $15 \mathrm{MPa}$ at $623 \mathrm{~K}$.

The vertical movement of the reaction mixture in the reactor is achieved by installing a cylindrical tube in the reactor vessel. When the mixer is in operation, the reaction mixture is circulated upwards through the inner space of the pipe and down into the space between the reactor vessel and the pipe.

In the case of feedstock oxidation with water, we separated the water phase and then divided and analyzed oxidate phase according to the scheme shown in Fig. 1.

Distillation was carried out by the Engler's method. Adsorption was performed by the developed method with silica gel as adsorbents. Benzene was used for the refined fuel desorption. The mixture of alcohol and benzene was applied for desorption of LCOP.

Feedstock and products were analyzed using standard methods. Lubricity was evaluated by the highfrequency reciprocating rig (HFRR) in accordance with ISO 12156-1:2006.

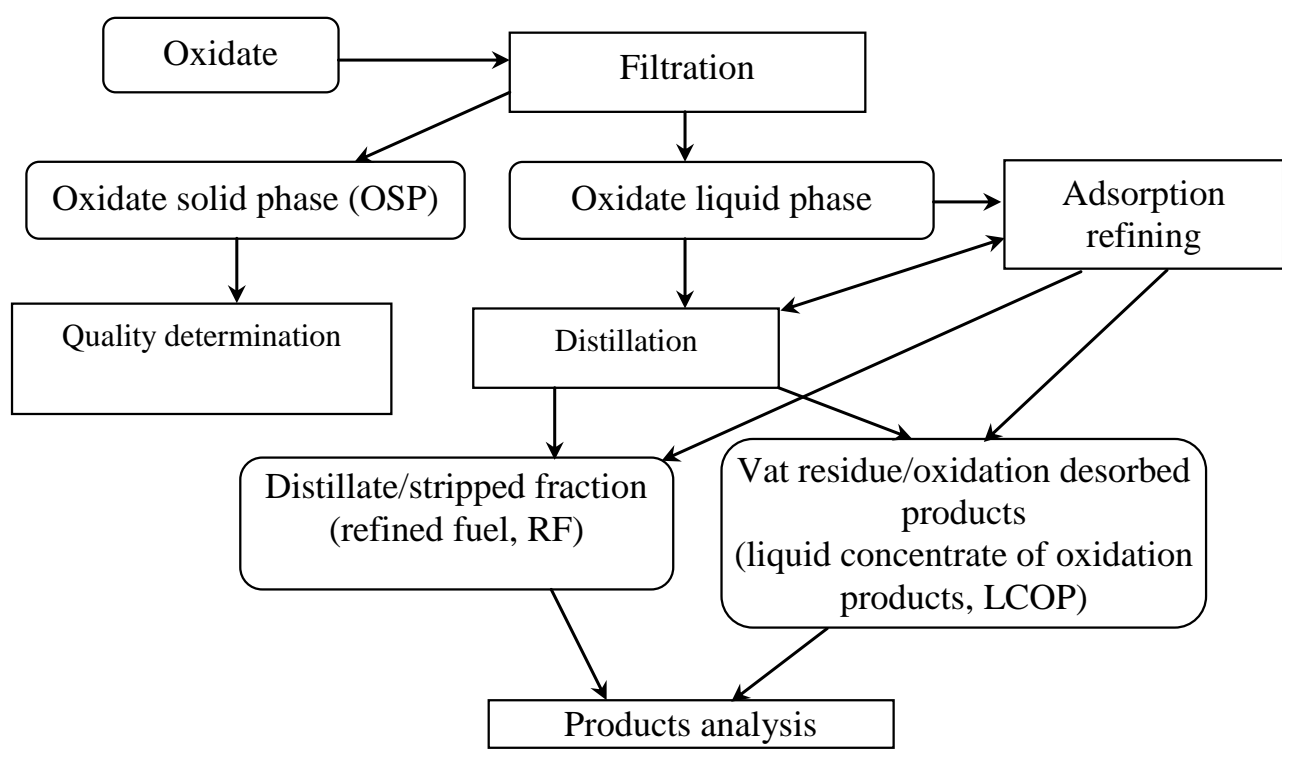

Fig. 1. Scheme of oxidate division and investigation 
Table 1

Characteristics of initial straight-run kerosene fraction

\begin{tabular}{|c|c|}
\hline Index & $\begin{array}{l}\text { Straight-run kerosene fuel from OJSC } \\
\text { "Galychyna" (SRKF) }\end{array}$ \\
\hline Density at $293 \mathrm{~K}, \mathrm{~kg} / \mathrm{m}^{3}$ & 788 \\
\hline Distillation characteristics & \\
\hline Initial boiling point, $\mathrm{K}$ & 411 \\
\hline $10 \%(\mathrm{v} / \mathrm{v})$ distilled at temperature, $\mathrm{K}$ & 434 \\
\hline $50 \%(\mathrm{v} / \mathrm{v})$ distilled at temperature, $\mathrm{K}$ & 456 \\
\hline $90 \%(\mathrm{v} / \mathrm{v})$ distilled at temperature, $\mathrm{K}$ & 493 \\
\hline $98 \%(\mathrm{v} / \mathrm{v})$ distilled at temperature, $\mathrm{K}$ & 565 \\
\hline Kinematic viscosity at $293 \mathrm{~K}, \mathrm{~mm}^{2} / \mathrm{s}$ & 1.45 \\
\hline Low heat value, $\mathrm{kJ} / \mathrm{kg}$ & 43209 \\
\hline Smoke point, $\mathrm{mm}$ & 13 \\
\hline Acidity, $\mathrm{mg} \mathrm{KOH} / 100 \mathrm{~cm}^{3}$ & 0.7 \\
\hline Iodine number, $\mathrm{g} \mathrm{I}_{2}$ per $100 \mathrm{~g}$ & 0.41 \\
\hline Closed flash point, $\mathrm{K}$ & 307 \\
\hline Wax appearance point, $\mathrm{K}$ & 209 \\
\hline Thermooxidative stability under static mode at $423 \mathrm{~K}, \mathrm{mg}$ per $100 \mathrm{~cm}^{3}$ & 33.3 \\
\hline Content of aromatic hydrocarbons, wt \% & 27 \\
\hline Content of actual gums, $\mathrm{mg} / 100 \mathrm{~cm}^{3}$ & 9.0 \\
\hline Content of total sulfur, wt \% (ppm) & $0.151(1510)$ \\
\hline Content of sour sulfur, wt \% (ppm) & $0.0063(63)$ \\
\hline Content of $\mathrm{H}_{2} \mathrm{~S}$ & absent \\
\hline Copper strip corrosion test & stands the test \\
\hline Ash content, wt \% & 0.0014 \\
\hline Content of mechanical impurities & absent \\
\hline Content of water & absent \\
\hline Reacting with water, points & 1 \\
\hline Electric conductivity at $293 \mathrm{~K}, \mathrm{pS} / \mathrm{m}$ & 12 \\
\hline
\end{tabular}

Table 2

Characteristics of initial diesel fraction

\begin{tabular}{|c|c|c|c|}
\hline Index & $\begin{array}{c}\text { Straight-run diesel fuel } \\
\text { from OJSC "Galychyna" } \\
\text { (SRDF) }\end{array}$ & $\begin{array}{l}>593 \mathrm{~K} \text { fraction from } \\
\text { SRDF (>593 K fr) }\end{array}$ & $\begin{array}{l}\text { Hydrofined diesel fuel } \\
\text { from OJSC } \\
\text { "Ukrtatnafta" (HDF) }\end{array}$ \\
\hline Cetane number & 45 & - & - \\
\hline $\begin{array}{l}\text { Distillation characteristics, } \\
50 \%(\mathrm{~V} / \mathrm{V}) \text { recovered at temperature, } \mathrm{K} \\
90 \%(\mathrm{~V} / \mathrm{V}) \text { recovered at temperature, } \mathrm{K} \\
\end{array}$ & $\begin{array}{r}548 \\
619 \\
\end{array}$ & $\begin{array}{l}- \\
- \\
\end{array}$ & $\begin{array}{l}554 \\
631 \\
\end{array}$ \\
\hline Kinematic viscosity at $293 \mathrm{~K}, \mathrm{~mm}^{2} / \mathrm{s}$ & 5.2 & - & - \\
\hline Pour point, $\mathrm{K}$ & 257 & - & -9 \\
\hline Flash point in closed crucible, $\mathrm{K}$ & 351 & - & \\
\hline Content of total sulfur, wt \% (ppm) & $0.250(2500)$ & $0.671(6710)$ & $0.055(550)$ \\
\hline Content of sour sulfur, wt \% (ppm) & $0.013(130)$ & - & $0.001(10)$ \\
\hline Content of $\mathrm{H}_{2} \mathrm{~S}$ & absent & - & absent \\
\hline Copper strip corrosion test & stands the test & - & stands the test \\
\hline Concentration of actual gums, $\mathrm{mg} / 100 \mathrm{~cm}^{3}$ & 28 & 49 & 12 \\
\hline Acidity, mg KOH/100 $\mathrm{cm}^{3}$ & 2.8 & 11.5 & 0.0 \\
\hline Iodine number, $\mathrm{g}$ iodine $/ 100 \mathrm{~g}$ & 3.74 & - & - \\
\hline Ash content, wt \% & 0.030 & - & - \\
\hline Coking ability of $10 \mathrm{vol} \%$ residue, $\%$ & 0.23 & - & 0.01 \\
\hline Filtration coefficient & 0.15 & - & - \\
\hline Content of mechanical impurities & absent & - & absent \\
\hline Content of water & absent & - & absent \\
\hline Density at $293 \mathrm{~K}, \mathrm{~kg} / \mathrm{m}^{3}$ & 838 & 869 & 839 \\
\hline
\end{tabular}




\subsection{Initial Materials}

The gas and diesel fractions were withdrawn at OJSC "Galychyna" (Drogobych, Ukraine) and OJSC "Ukrtatnafta" (Kremenchuk, Ukraine) and used for studying the hydrodynamic parameters.

The characteristics of the initial kerosene fraction are presented in Table 1.

The characteristics of the initial diesel fraction are presented in Table 2. To increase the concentration of sulfur compounds in the initial diesel, a residual fraction $(>593 \mathrm{~K})$ was distilled from it. This made it possible to compare the effect of hydrodynamic parameters on the desulfurization process of feedstock with a significantly different sulfur content.

\subsection{Processing of Results}

The sulfur removal degree (RDS, \%) was calculated in accordance with the formula (1):

$$
R D S=\frac{S_{t 0}-S_{t}}{S_{t 0}} \cdot 100
$$

where $S_{t 0}$ is the content of total sulfur in the initial feedstock, wt $\% ; S_{t}$ is the content of total sulfur in refined fuel, wt $\%$.

The yield of oxidate phase (OF, solid phase + + liquid phase), oxidate solid phase (OSP), refined fuel (RF), and liquid concentrate of oxidation products (LCOP) were calculated in accordance with Fig. 1.

To characterize the hydrodynamic parameters of the oxidant motion and to calculate the basic dimensions of the reactor during its simulation (reproduction), linear rate of the oxidant (LRO) and time of contact between the feedstock and oxidant (hereinafter referred to as a dummy contact time) were calculated.

LRO was calculated as the ratio between volumetric flow rate of oxidant $\left(\mathrm{m}^{3} / \mathrm{s}\right)$ and the cross-sectional area of the reactor $\left(\mathrm{m}^{2}\right)$. To simplify the model description LRO was determined under normal conditions. The dummy contact time $(\tau$, s), was calculated as the ratio of the feedstock layer height $(\mathrm{m})$ to $\mathrm{LRO}(\mathrm{m} / \mathrm{s})$.

To describe the air: feedstock ratio, time and contact area between them we used the term "volumetric oxidant flow rate" (VOFR, $\mathrm{min}^{-1}$ ), which is numerically equal to the ratio of oxidant consumption $\left(\mathrm{m}^{3} / \mathrm{min}\right.$ ) to the feedstock volume $\left(\mathrm{m}^{3}\right)$.

A modified Reynolds criterion was calculated to characterize the stirring intensity of reaction medium:

$$
R e_{m}=\frac{n d_{x}}{v_{w}}
$$

where $n$ is the stirrer speed, rpm; $d_{x}=\frac{D_{r} \cdot d_{s}}{d_{c}^{2}}$ is a modified characteristic parameter of the reactor equal to
1.725; $D_{r}, d_{s}$ and $d_{c}$ are the diameters of a reactor, stirrer and circulating tube, respectively, $\mathrm{m} ; v_{w}$ is a viscosity of water at $293 \mathrm{~K}$.

The reactor, stirrer and circulation pipe had the following geometric parameters: $D_{r} / d_{c}=2.27 ; d_{s} / d_{c}=$ $=0.76$; reactor height / circulation pipe height $H / h=2.47$; inclination of the stirrer blades is $35-45^{\circ}$; the number of holes for air supply is 225 per $1 \mathrm{~m}^{2}$.

\section{Results and Discussion}

The process of oxidation desulfurization (OD) under study is a heterophase one. There are four phases in contact: air (gas), feedstock (liquid), water (liquid), solid oxidation products (solid phase). There is no information in the literature about the hydrodynamics of such a system in a vertical stirred reactor. The study of hydrodynamics is also complicated by changes in medium characteristics over time, high temperatures and pressures.

Gun and Levich $[23,24]$ found the residence time of the gaseous reagent in the liquid medium and the surface of the interfacial contact to be the main factors of the process that determine the rate of gas reaction components transition (in this case, oxygen) to liquid reagents in a two-phase reaction system liquid:gas. Direct determination of these parameters during the OD process for liquid fuels is practically impossible. In turn, they depend on a number of process factors, the main of which are gas flow velocity, liquid to gas ratio, reactor design, liquid characteristics (first of all, density and viscosity). So, in order to simplify the description of the hydrodynamics, the following parameters were used for all experiments carried out without stirring the reaction medium: the air : feedstock ratio $\left(\mathrm{VOFR}, \mathrm{min}^{-1}\right)$; linear rate of the oxidant ( $\mathrm{LRO}, \mathrm{m} / \mathrm{s})$; dummy contact time between the liquid and gaseous phases $\left(\tau_{f}, \mathrm{~s}\right)$. The calculation procedures for these parameters are given in Subsection 2.3. To characterize the process under stirring, the reactor geometric parameters and the value of stirrer speed were used. Section 2.3 describes the relationship between the stirrer speed and the modified Reynolds criterion. The above indices and criteria are not true values characterizing the hydrodynamic regime of the system, the area and the contact time of feedstock with the oxidizer in the presence of water. However, knowing these parameters makes it easy to reproduce (simulate) the process in another reactor.

The studies were carried out at different values of VOFR and constant temperature, pressure and water feedstock ratios. Distillation was used to extract the LCOP (OLP obtained from SRDF was distilled to $553 \mathrm{~K}$; the $>593 \mathrm{~K} \mathrm{fr}-$ to $623 \mathrm{~K}$ ). The results obtained are presented in Tables 3-4. 
Table 3

Effect of LRO and $\tau_{\mathrm{f}}$ on the main products yield

\begin{tabular}{|c|c|c|c|c|c|c|}
\hline \multirow{2}{*}{ Entry } & \multirow{2}{*}{$\mathrm{LRO}, \mathrm{m} / \mathrm{s}$} & \multirow{2}{*}{$\tau_{f}, \mathrm{~S}$} & \multicolumn{4}{|c|}{ Yield relative to the feedstock, wt $\%$} \\
\hline & & & $\mathrm{OF}$ & OSP & RF & LCOP \\
\hline \multicolumn{7}{|c|}{ VOFR $=1.080 \mathrm{~min}^{-1}$ (feedstock is SRDF) } \\
\hline 1 & 0.0013 & 56 & 98.61 & 0.03 & 95.03 & 3.55 \\
\hline 2 & 0.0026 & 56 & 98.65 & 0.08 & 94.89 & 3.68 \\
\hline 3 & 0.0031 & 56 & 98.81 & 0.09 & 94.8 & 3.92 \\
\hline \multicolumn{7}{|c|}{ VOFR $=2.160 \mathrm{~min}^{-1}$ (feedstock is SRDF) } \\
\hline 4 & 0.0026 & 28 & 97.99 & 0.08 & 94.12 & 3.79 \\
\hline \multicolumn{7}{|c|}{ VOFR $=2.160 \mathrm{~min}^{-1}$ (feedstock is SRDF) } \\
\hline 5 & 0.0091 & 28 & 98.29 & 0.15 & 94.02 & 4.12 \\
\hline 6 & 0.0104 & 28 & 98.20 & 0.20 & 93.79 & 4.21 \\
\hline 7 & 0.0143 & 28 & 97.99 & 0.16 & 93.75 & 4.08 \\
\hline 8 & 0.0208 & 28 & 98.01 & 0.22 & 93.68 & 4.11 \\
\hline \multicolumn{7}{|c|}{ VOFR $=1.650 \mathrm{~min}^{-1}$ (feedstock is $>593 \mathrm{~K} \mathrm{fr}$ ) } \\
\hline 9 & 0.0015 & 35 & 97.56 & 0.18 & 85.61 & 11.77 \\
\hline 10 & 0.0030 & 35 & 97.34 & 0.29 & 85.40 & 11.65 \\
\hline 11 & 0.0056 & 36 & 96.90 & 0.47 & 85.09 & 11.34 \\
\hline \multicolumn{7}{|c|}{ VOFR $=0.825 \mathrm{~min}^{-1}$ (feedstock is $>593 \mathrm{~K} \mathrm{fr}$ ) } \\
\hline 12 & 0.0015 & 69 & 97.66 & 0.25 & 85.42 & 11.99 \\
\hline \multicolumn{7}{|c|}{ VOFR $=1.212 \mathrm{~min}^{-1}$ (feedstock is $>593 \mathrm{~K} \mathrm{fr}$ ) } \\
\hline 13 & 0.0045 & 23 & 96.95 & 0.80 & 84.98 & 11.17 \\
\hline
\end{tabular}

Table 4

Effect of LRO and $\tau_{f}$ on the RF characteristics

\begin{tabular}{|c|c|c|c|c|c|c|}
\hline \multirow[b]{2}{*}{ Entry } & \multirow{2}{*}{$\begin{array}{c}\mathrm{LRO}, \\
\mathrm{m} / \mathrm{s}\end{array}$} & \multirow[b]{2}{*}{$\begin{array}{l}\tau_{f} \\
\mathrm{~s}\end{array}$} & \multicolumn{4}{|c|}{ Index } \\
\hline & & & $\begin{array}{l}\text { Content of total sulfur, } \\
\text { wt } \%\end{array}$ & $\begin{array}{c}\text { Concentration of actual gums, } \\
\mathrm{mg} / 100 \mathrm{~cm}^{3}\end{array}$ & $\begin{array}{c}\text { Acidity, } \\
\mathrm{mg} \mathrm{KOH} / 100 \mathrm{~cm}^{3}\end{array}$ & $\begin{array}{c}\mathrm{RDS}, \\
\%\end{array}$ \\
\hline \multicolumn{7}{|c|}{ VOFR $=1.080 \mathrm{~min}^{-1}$ (feedstock is SRDF) } \\
\hline 1 & 0.0013 & 56 & 0.086 & 0.8 & 17.6 & 43.05 \\
\hline 2 & 0.0026 & 56 & 0.061 & 1.2 & 22.4 & 59.60 \\
\hline 3 & 0.0031 & 56 & 0.059 & 2.0 & 27.61 & 60.93 \\
\hline \multicolumn{7}{|c|}{ VOFR $=2.160 \mathrm{~min}^{-1}$ (feedstock is SRDF) } \\
\hline 4 & 0.0026 & 28 & 0.064 & 1.6 & 28.5 & 57.62 \\
\hline \multicolumn{7}{|c|}{ VOFR $=2.160 \mathrm{~min}^{-1}$ (feedstock is SRDF) } \\
\hline 5 & 0.0091 & 28 & 0.062 & 2.1 & 31.8 & 58.94 \\
\hline 6 & 0.0104 & 28 & 0.064 & 2.2 & 32.2 & 57.62 \\
\hline 7 & 0.0143 & 28 & 0.060 & 2.2 & 31.9 & 60.26 \\
\hline 8 & 0.0208 & 28 & 0.061 & 2.3 & 32.1 & 59.60 \\
\hline \multicolumn{7}{|c|}{ VOFR $=1.650 \mathrm{~min}^{-1}$ (feedstock is $>593 \mathrm{~K} \mathrm{fr}$ ) } \\
\hline 9 & 0.0015 & 35 & 0.422 & 25 & 16.9 & 37.11 \\
\hline 10 & 0.0030 & 35 & 0.383 & 39 & 22.8 & 42.92 \\
\hline 11 & 0.0056 & 36 & 0.381 & 43 & 24.8 & 43.22 \\
\hline \multicolumn{7}{|c|}{ VOFR $=0.825 \mathrm{~min}^{-1}$ (feedstock is $>593 \mathrm{~K} \mathrm{fr}$ ) } \\
\hline 12 & 0.0015 & 69 & 0.382 & 19 & 15.8 & 43.07 \\
\hline \multicolumn{7}{|c|}{ VOFR $=1.212 \mathrm{~min}^{-1}$ (feedstock is $>593 \mathrm{~K} \mathrm{fr}$ ) } \\
\hline 13 & 0.0045 & 23 & 0.490 & 59 & 25.7 & 26.97 \\
\hline
\end{tabular}

The increase in LRO value from $0.0013-0.0015$ to $0.0026-0.0030 \mathrm{~m} / \mathrm{s}$ intensifies the oxidation of sulfur compounds and the hydrocarbon medium as well, resulting in the increase of RDS, OSP yield, acidity and concentra- tion of actual gums in the final products (especially when using diesel fraction). Further increase in LRO value to $0.0091 \mathrm{~m} / \mathrm{s}$ has minor or no effect on the oxidation intensity and sulfur removal and insignificantly increases 
the intensity of the hydrocarbon medium oxidation. The increase in LRO value from 0.0091 to $0.0208 \mathrm{~m} / \mathrm{s}$ has no effect on the main characteristics of the process (entries 48, Tables 3-4).

The increase in dummy contact time from 28-35 to 56-69 s slightly affects the amount of removed sulfur. This could be explained by the lack of oxygen (70-80\% was used) to accomplish the process. During SRDF desulfurization, the amount of oxygen exceeded the theoretically required value by 4-8 times to oxidize all sulfur compounds to sulfones. When the diesel fraction $>593 \mathrm{~K}$ was desulfurized, the amount of oxygen exceeded the theoretically required value by only 1.25 times at VOFR $=$ $0.825 \mathrm{~min}^{-1}$, and by 2.5 times at VOFR $=1.650 \mathrm{~min}^{-1}$.

When the fraction $>593 \mathrm{~K}$ fr was oxidized by oxygen-enriched air at VOFR $=0.825 \mathrm{~min}^{-1}$ and $\mathrm{O}_{2}$ content of $45 \mathrm{vol} \%$ (the amount of oxygen was 2.5 times greater than theoretically required for the oxidation of all sulfur compounds to sulfones) under other identical conditions (entry 11, Tables 3-4), the sulfur content in distillate (refined fuel) was $0.350 \mathrm{wt} \%$ (the sulfur removal degree $47.76 \mathrm{wt} \%$ ). It means that with the same amount of oxygen, an increase in the dummy contact time from 36 to $69 \mathrm{~s}$ results in the increase of RDS value by less than $4.5 \%$.

Thus, we can assert that the minimum allowable values of LRO and $\tau_{f}$ are $0.0015-0.0030 \mathrm{~m} / \mathrm{s}$ and $28-35 \mathrm{~s}$ respectively. For the geometric dimensions of the reactor, given in Subsection 2.3, the determined parameters will provide the required modes of motion and the surface of oxygen contact with the reaction medium, and therefore, sufficient RDS.

To study the dependence of the process characteristics on the stirring intensity we also used $>593 \mathrm{~K} \mathrm{fr}$ and SRDF. The effect of stirring intensity on the OD process was studied for $5 \mathrm{~min}$ (for comparison, SRDF was oxidized for $20 \mathrm{~min}$ ). This period of time was chosen to exclude the possibility of oxidation due to the dissolved oxygen. The results obtained are presented in Tables 5-6.

In all cases, the presence and increase of the stirring intensity contributes to some decrease in the distillate yield, an increase in the LCOP amount and almost tenfold increase of the OSP yield (Table 5). At the process time of 5 minutes the distillate yield is higher and the amount of the solid phase is lower compared with those at 20 minutes, which is a consequence of the lower oxidation depth of the feedstock components. At the same time, the increase in stirring intensity has no noticeable effect on the total amount of oxidate. The possible reason is the increase in the oxidation rate of the fuel hydrocarbon part and formation of greater amount of both soluble (LCOP) and insoluble (OSP) products occurred due to the better contact of oxygen and the feedstock with increased stirring intensity, regardless of the process time. The effect of the stirring intensity on the oxidation of the feedstock hydrocarbon part is confirmed by the data presented in Table 6 . With the increase in stirring intensity at $5 \mathrm{~min}$ and at $20 \mathrm{~min}$ the concentration of actual gum in the distillate increases by 2-10 times and distillate acidity by $2-3$ times.

Table 5

Effect of stirring intensity on the main products yield

\begin{tabular}{|c|c|c|c|c|}
\hline \multirow{2}{*}{$\mathrm{Re}_{\mathrm{m}}$} & \multicolumn{4}{|c|}{ Yield relative to the feedstock, wt $\%$} \\
\hline & $\mathrm{OF}$ & OSP & $\mathrm{RF}$ & LCOP \\
\hline \multicolumn{5}{|c|}{5 min (feedstock is SRDF) } \\
\hline 0 & 99.57 & 0.02 & 96.04 & 3.51 \\
\hline $8.59 \cdot 10^{8}$ & 99.28 & 0.15 & 95.59 & 3.54 \\
\hline $3.44 \cdot 10^{9}$ & 99.04 & 0.24 & 95.18 & 3.62 \\
\hline $6.87 \cdot 10^{9}$ & 98.86 & 0.29 & 94.86 & 3.71 \\
\hline \multicolumn{5}{|c|}{$20 \mathrm{~min}$ (feedstock is SRDF) } \\
\hline 0 & 97.51 & 0.09 & 93.76 & 3.66 \\
\hline $8.59 \cdot 10^{8}$ & 97.32 & 0.64 & 93.02 & 3.66 \\
\hline $3.44 \cdot 10^{9}$ & 97.24 & 0.83 & 92.44 & 3.97 \\
\hline $6.87 \cdot 10^{9}$ & 96.74 & 0.89 & 91.85 & 4.00 \\
\hline \multicolumn{5}{|c|}{$5 \mathrm{~min}$ (feedstock is $>593 \mathrm{~K} \mathrm{fr}$ ) } \\
\hline 0 & 98.96 & 0 & 87.91 & 11.05 \\
\hline $8.59 \cdot 10^{8}$ & 98.73 & 0.32 & 87.02 & 11.39 \\
\hline $3.44 \cdot 10^{9}$ & 98.86 & 0.87 & 86.58 & 11.41 \\
\hline
\end{tabular}


Effect of stirring intensity on the RF characteristics

\begin{tabular}{|c|c|c|c|c|}
\hline \multirow[b]{2}{*}{$\operatorname{Re}_{\mathrm{M}}$} & \multicolumn{4}{|c|}{ Index } \\
\hline & $\begin{array}{c}\text { Content of total sulfur, } \\
\text { wt } \%\end{array}$ & $\begin{array}{c}\text { Concentration of actual gums, } \\
\mathrm{mg} / 100 \mathrm{~cm}^{3}\end{array}$ & $\begin{array}{c}\text { Acidity, } \\
\mathrm{mg} \mathrm{KOH} / 100 \mathrm{~cm}^{3}\end{array}$ & $\begin{array}{c}\mathrm{RDS}, \\
\%\end{array}$ \\
\hline \multicolumn{5}{|c|}{$5 \mathrm{~min}$ (feedstock is SRDF) } \\
\hline 0 & 0.106 & 1.0 & 6.7 & 29.80 \\
\hline $8.59 \cdot 10^{8}$ & 0.104 & 1.6 & 8.4 & 31.13 \\
\hline $3.44 \cdot 10^{9}$ & 0.101 & 2.5 & 10.5 & 33.11 \\
\hline $6.87 \cdot 10^{9}$ & 0.099 & 3.5 & 12.3 & 34.44 \\
\hline \multicolumn{5}{|c|}{$20 \mathrm{~min}$ (feedstock is SRDF) } \\
\hline 0 & 0.052 & 1.70 & 24.3 & 65.56 \\
\hline $8.59 \cdot 10^{8}$ & 0.051 & 4.00 & 37.4 & 66.23 \\
\hline $3.44 \cdot 10^{9}$ & 0.052 & 5.80 & 39.5 & 65.56 \\
\hline $6.87 \cdot 10^{9}$ & 0.060 & 11 & 40.2 & 60.26 \\
\hline \multicolumn{5}{|c|}{$5 \mathrm{~min}$ (feedstock is $>593 \mathrm{~K} \mathrm{fr}$ ) } \\
\hline 0 & 0.376 & 39 & 22.8 & 43.96 \\
\hline $8.59 \cdot 10^{8}$ & 0.354 & 54 & 29.7 & 47.24 \\
\hline $3.44 \cdot 10^{9}$ & 0.339 & 71 & 63.4 & 49.48 \\
\hline
\end{tabular}

On the other hand, the oxidation depth of the sulfur compounds is slightly affected by the stirring intensity: RDS value increases by 1.10-1.15 times maximum. At the process time of 20 min with the increase in $\mathrm{Re}_{\mathrm{m}}$ value this index even tends to decrease. This is due to the fact that the intensification of the hydrocarbons oxidation reduces the selectivity of sulfur compounds removal. In addition, the sulfur compounds remaining in the RF are distributed in a smaller volume as the distillate yield decreases. Instead, at the process time of $5 \mathrm{~min}$, the value of RDS tends to increase slightly, because for short process time the oxidation rate of sulfur compounds may depend on the contact phase surface, i.e., on the stirring intensity of the reaction medium.

Thus, for LRO values less than $0.0015-0.0030 \mathrm{~m} / \mathrm{s}$ and process time greater than $5 \mathrm{~min}$, the oxidation rate of sulfur compounds is practically independent of the stirring intensity and, consequently, the contact area air-feedstock (the contact area of the reacting phases). It means that the process proceeds in the kinetic region. In this case, $\tau_{f}$ should exceed 28-35 s. Oxidation of the fuel hydrocarbon part occurs in the diffusion region, so the stirring intensifies the hydrocarbons oxidation, and negatively affects the process characteristics. Therefore, when carrying out the oxidation process without stirring the reaction medium selectivity will increase.

As can be seen from the data obtained, it is possible to reduce the sulfur content in SRDF (meets the requirements of both European and Ukrainian standards). It is impossible for the fraction $>593 \mathrm{~K}$ fr. The reasons are the high sulfur content in the feedstock, other non-optimal process factors, and application of distillation for the separation of liquid products instead of its combination with adsorption. On the other hand, with stricter requirements for the sulfur content in diesel fuel (0.05$0.035 \mathrm{wt} \%$ or $500-350 \mathrm{ppm})$ the resulting products will not be able to be obtained by the described method. In this case, it is suggested to use an oxidation plant for the aftertreatment of the hydrotreated diesel fractions.

So the next step was to study the oxidation desulfurization of hydrogenate under optimum hydrodynamic parameters. The hydrogenate from the wide diesel fraction was withdrawn at OJSC Ukrtatnafta (Kremenchuk, Ukraine) and contained $0.055 \mathrm{wt} \%$ of sulfur. Distillation or adsorption was used to separate RF and LCOP. The experimental results are presented in Tables 7-8.

Table 7

Main products yield

\begin{tabular}{|c|c|c|c|c|c|}
\hline \multirow{2}{*}{ Entry } & \multirow{2}{*}{ Feedstock } & \multicolumn{4}{|c|}{ Yield relative to the feedstock, wt \% } \\
\cline { 3 - 6 } & & OF & OSP & RF & LCOP \\
\hline 1 & HDF & 98.42 & 0.43 & $95.24^{1}$ & 3.18 \\
\hline 2 & HDF & 98.42 & 0.43 & $95.93^{2}$ & 2.49 \\
\hline
\end{tabular}

Notes: ${ }^{1}$ distillation was used to separate RF and LCOP; ${ }^{2}$ adsorption was used to separate RF and LCOP/ 
RF characteristics

\begin{tabular}{|c|c|c|c|c|c|}
\hline \multirow{2}{*}{ Entry } & \multirow{2}{*}{\begin{tabular}{c} 
Product \\
\cline { 3 - 6 }
\end{tabular}} & $\begin{array}{c}\text { Content of total sulfur, } \\
\text { wt } \%\end{array}$ & $\begin{array}{c}\text { Concentration of actual gums, } \\
\mathrm{mg} / 100 \mathrm{~cm}^{3}\end{array}$ & $\begin{array}{c}\text { Acidity, } \\
\mathrm{mg} \mathrm{KOH} / 100 \mathrm{~cm}^{3}\end{array}$ & $\begin{array}{c}\text { RDS, } \\
\%\end{array}$ \\
\hline 1 & $\mathrm{RF}^{1}$ & 0.008 & 11 & $2.1^{3}$ & 85.45 \\
\hline 2 & $\mathrm{RF}^{2}$ & 0.004 & 8.3 & 3.0 & 92.73 \\
\hline
\end{tabular}

Notes: ${ }^{1}$ distillation was used to separate RF and LCOP; ${ }^{2}$ adsorption was used to separate RF and LCOP; ${ }^{3}$ RF was alkali treated, the yield of the products after treatment was $0.71 \mathrm{wt} \%$ relative to distillate, the sulfur content of the non-alkaline distillate was 0.008 wt $\%$.

Table 9

Characteristics of the samples used to assay the lubricity of initial materials and obtained products

\begin{tabular}{|c|l|}
\hline Sample No. & \multicolumn{1}{|c|}{ Characteristics } \\
\hline 1 & HDF (Table 1) \\
\hline 2 & $\begin{array}{l}\text { 438-623 K straight-run diesel fraction from OJSC "Naftokhimik Prykarpattya". Content of total sulfur was } \\
0.671 \mathrm{wt} \%(6710 \mathrm{ppm})\end{array}$ \\
\hline 3 & $\begin{array}{l}438-623 \mathrm{~K} \text { desulfurized fraction from OJSC "Naftokhimik Prykarpattya". Content of total sulfur was 0.138 } \\
\text { wt \% (1380 ppm) }\end{array}$ \\
\hline
\end{tabular}

Table 10

Tribological test results of investigated samples

\begin{tabular}{|c|c|c|c|}
\hline Sample No. & Corrected wear scar diameter, $\mu \mathrm{m}$ & Friction coefficient & Lubricating film thickness, $\%$ \\
\hline 1 & 530 & 0.388 & 12 \\
\hline 2 & 569 & 0.242 & 7 \\
\hline 3 & 386 & 0.204 & 55 \\
\hline
\end{tabular}

As can be seen from the obtained results, by means of the developed process it is possible to remove at least $80 \%$ of sulfur remaining after hydrotreating, even when only distillation is used for the separation.

Since one of the main drawbacks of the hydrotreating is the reduction of fuels lubricating properties, an effect of the developed process on this index was studied. The characteristics of the analyzed samples are presented in Table 9, and tribological test results - in Table 10. To obtain the sample No.3 (Table 9) the OD was used under conditions close to the optimum ones using the determined hydrodynamic parameters. A combination of adsorption and distillation was used to separate RF and LCOP. To reduce the acidity of the refined fuel the alkali treatment was applied after the process; the alkali amount was $100 \mathrm{mg} \mathrm{KOH}$ per $100 \mathrm{~cm}^{3}$ of the product, $2 \%(\mathrm{wt} / \mathrm{wt}$ ) aqueous solutionю

The results of tribological tests performed for the samples are given in Table 10.

The results of tribological tests confirm that the fraction $438-623 \mathrm{~K}$ after oxidative desulfurization and "mild" alkali treatment (the sample No.3) has a higher lubricity compared with the hydrotreated diesel fuel (the sample No.1) and initial straight-run diesel fraction (the sample No.2); the corrected wear scar diameter and friction coefficient are lower and the lubricating films thickness is higher. The corrected wear scar diameter of the sample No.3 is less than the limit value for the diesel fuels $(460 \mu \mathrm{m})$ in accordance with ISO 12156-2:2077. The improvement in the lubricity of the sample is probably caused by the oxygen-containing compounds remaining in it.

\section{Conclusions}

In order the sulfur compounds oxidation reactions proceed in the kinetic region without mechanical stirring of the reaction medium, it is sufficient to provide the LRO higher than $0.0015-0.0026 \mathrm{~m} / \mathrm{s}$. The minimum allowable dummy contact time between the oxidizer and the feedstock should be $28-35 \mathrm{~s}$.

Due to the developed non-catalytic oxidative desulfurization process it is possible to use the straight-run diesel fuel fraction with the sulfur content of $6710 \mathrm{ppm}$ as the raw material to obtain the diesel fuel with the sulfur content of $1380 \mathrm{ppm}$ that meets the standard of Ukraine (DSTU 8705:2017).

The hydrotreated diesel fuel with the sulfur content of $550 \mathrm{ppm}$ may be desulfurized by the developed method to obtain the diesel fuel with $40 \mathrm{ppm}$ of sulfur that meets 
the standards of Ukraine (DSTU 4840:2007 and DSTU 7688:2015).

Fuels after oxidation have a higher lubricity compared with the initial straight-run diesel fraction and the initial hydrotreated diesel fuel. The suggested method allows to obtain the products, which may be used as components or additives for hydrotreated fuels and improve their lubricity.

\section{References}

[1] Ismagilov Z., Yashnik S., Kerzhentsev M. et al.: Cat. Rev. Sci. Eng., 2011, 53, 199. https://doi.org/10.1080/01614940.2011.596426 [2] Regulatory Impact Analysis: Heavy-Duty Engine and Vehicle Standards and Highway Diesel Fuel Sulfur Control Requirements. United States Environmental Protection Agency, Air and Radiation, EPA420-R-00-026, December 2000.

[3] United States Environmental Protection Agency, February, 2001. https://www.epa.gov

[4] Directive 2010/75/EU of the European Parliament and of the Council of 24 November 2010 on industrial emissions (integrated pollution prevention and control).

http://data.europa.eu/eli/dir/2010/75/oj

[5] Link D., Baltrus J., Rothenberger K. et al.: Energ. Fuel., 2003,

17, 1292. https://doi.org/10.1021/ef0300747

[6] World jet fuel specifications. 2008.

http://large.stanford.edu/courses/2017/ph240/chhoa1/docs/exxon2008.pdf

[7] Boichenko S., Vovk O., Iakovlieva, A.: Chem. Chem. Technol., 2013, 7, 305. https://doi.org/10.23939/chcht07.03.305

[8] Yakovleva A., Boichenko S., Lejda K. et al.: Chem. Technolog. Fuels Oils, 2017, 53, 1. https://doi.org/10.1007/s10553-017-0774-x [9] Iakovlieva A., Boichenko S., Gay A.: Chem. Chem. Technol., 2014, 8, 107. https://doi.org/10.23939/chcht08.01.107

[10] Banisharif F., Dehghani M., Capel-Sánchez M., Campos-

Martin J.: Ind. Eng. Chem. Res., 2017, 56, 3839.

https://doi.org/10.1021/acs.iecr.7b00089

[11] Babich I., Moulijn J.: Fuel, 2003, 82, 607.

https://doi.org/10.1016/S0016-2361(02)00324-1

[12] Wang B., Dai B., Kang L., Zhu M.: Fuel, 2020, 265, 117029.

[13] Liu W., Li T., Yu G. et al.: Fuel, 2020, 265, 116967.

https://doi.org/10.1016/j.fuel.2019.116967

[14] Mirante F., Alves A. et al.: Fuel, 2020, 259, 116213.

https://doi.org/10.1016/j.fuel.2019.116213
[15] Julião D., Mirante F. et al.: Fuel, 2019, 241, 616.

https://doi.org/10.1016/j.fuel.2018.11.095

[16] Pysh'yev S., Bratychak M., Lazorko O., Shyshchak O.: Pol. J. Environ. Stud., 2005, 14, 123.

[17] Lazorko O., Pysh'yev S., Bratychak M.: Chem.Chem.Technol., 2008, 2, 309.

[18] Pysh'yev S., Lazorko O., Bratychak M.: Chem. Chem.

Technol., 2009, 3, 77.

[19] Pysh'yev S., Lazorko O., Bratychak M.: Chem. Chem.

Technol., 2009, 3, 163.

[20] Paniv P., Pysh'yev S., Haivanovych V., Lazorko O.: Khimia i

Technologia Topliva i Masel, 2006, 3, 7.

[21] Pysh'yev S.: Chem. Chem. Technol., 2012, 6, 229.

https://doi.org/10.23939/chcht06.02.229

[22] Antonyshyn V., Humenetsky V.: Visnyk Nats. Univ. Lvivska Polytechnika, 1974, 82, 94.

[23] Gun R.: Neftianye Bitumy. Lhimia, Moskva 1973.

[24] Levych V.: Physico-Khimicheskaya Hydrodynamika. Izd-vo AN SSSR, Moskva 1952.

Received: May 15, 2019 / Revised: July 22, 2019 / Accepted: December 01, 2019

\section{ДОСЛІДЖЕННЯ ГІДРОДИНАМІЧНИХ ПАРАМЕТРІВ ОКСИДАЦЙНОГО ЗНЕСІРЧЕННЯ ПРЯМОГОННИХ НАФТОВИХ ФРАКЦЙ 3 ВИСОКИМ ВМІСТОМ СІРКИ}

Анотація. Встановлено необхідні гідродинамічні параметри процесу знесірчення прямогонних гасових (SRKF) i дизельних фракиій (SRDF) внаслідок окиснення сірчистих органічних сполук з наступним вилученням продуктів окиснення. Гідродинамічні параметри, які характеризуються лінійною швидкістю руху оксиданту (повітря) та фіктивним часом контакту між оксидантом і сировиною, дають можливість здійснювати прочес без перемішування. Запропонована технологія може використовуватися для очищення нафтових палив малотонажних виробництв, коли економічно невигідно або технологічно неможливо використовувати гідроочищення. Показано, щуо даний прочес можна застосовувати для доочищення гідрогенізатів та часткового знесірчення прямогонних фракцій з метою виробництва компонентів палив з покращеними мастильними властивостями.

Ключові слова: сірка, реактивне паливо, дизельне паливо, оксидаційне знесірчення, гідродинамічні параметри, мастильна здатність. 